\title{
A quantitative assessment of the parameters of the role of receptionists in modern primary care using the work design framework
}

\author{
Michael Burrows ${ }^{1,2}$, Nicola Gale ${ }^{3}$, Sheila Greenfield ${ }^{1}$ and lan Litchfield ${ }^{1 *}$ (D)
}

\begin{abstract}
Background: Amidst increased pressures on General Practice across England, the receptionist continues to fulfil key administrative and clinically related tasks. The need for more robust support for these key personnel to ensure they stay focussed and motivated is apparent, however, to be effective a more systematic understanding of the parameters of their work is required. Here we present a valuable insight into the tasks they fulfil, their relationship with colleagues and their organisation and their attitudes and behaviour at work collectively defined as their 'work design'.

Methods: Our aim was to quantitatively assess the various characteristics of receptionists in primary care in England using the validated Work Design Questionnaire (WDQ) a 21 point validated questionnaire, divided into four categories: task, knowledge and social characteristics and work context with a series of sub-categories within each, disseminated online and as a postal questionnaire to 100 practices nationally.

Results: Seventy participants completed the WDQ, 54 online and 16 using the postal questionnaire with the response rate for the latter being 3.1\%. The WDQ suggested receptionists experience high levels of task variety, task significance and of information processing and knowledge demands, confirming the high cognitive load placed on receptionists by performing numerous yet significant tasks. Perhaps in relation to these substantial responsibilities a reliance on colleagues for support and feedback to help negotiate this workload was reported.

Conclusion: The evidence of our survey suggests that the role of modern GP receptionists requires an array of skills to accommodate various administrative, communicative, problem solving, and decision-making duties. There are ways in which the role might be better supported for example devising ways to separate complex tasks to avoid the errors involved with high cognitive load, providing informal feedback, and perhaps most importantly developing training programmes.
\end{abstract}

Keywords: Primary care, Health service delivery, Quantitative research

\footnotetext{
* Correspondence: i.litchfield@bham.ac.uk

1 Institute of Applied Health Research, College of Medical and Dental Sciences, University of Birmingham, Edgbaston, Birmingham B15 2TT, UK

Full list of author information is available at the end of the article
}

(c) The Author(s). 2020 Open Access This article is licensed under a Creative Commons Attribution 4.0 International License, which permits use, sharing, adaptation, distribution and reproduction in any medium or format, as long as you give appropriate credit to the original author(s) and the source, provide a link to the Creative Commons licence, and indicate if changes were made. The images or other third party material in this article are included in the article's Creative Commons licence, unless indicated otherwise in a credit line to the material. If material is not included in the article's Creative Commons licence and your intended use is not permitted by statutory regulation or exceeds the permitted use, you will need to obtain permission directly from the copyright holder. To view a copy of this licence, visit http://creativecommons.org/licenses/by/4.0/. The Creative Commons Public Domain Dedication waiver (http://creativecommons.org/publicdomain/zero/1.0/) applies to the data made available in this article, unless otherwise stated in a credit line to the data. 


\section{Background}

Over the last 15 years, general practice has experienced a profound increase in workload as the population ages and the complexity of care increases [1-4]. Demand has reached unprecedented levels $[2,5]$ and the primary care landscape is changing [6-8]. As a result, staff are now delivering care in a far more complex and dynamic environment with implications for clinical and non-clinical members of the primary care team. Amongst the most visible of these are receptionists who not only undertake an array of administrative duties $[9,10]$ but also fulfil clinically related tasks such as triaging patients, reporting results or administering screening [11-19] often without adequate training [10]. The failure of receptionists to successfully fulfil these responsibilities has potentially serious implications for patient outcomes and safety [15, 20-22].

The need for more robust support for these key personnel to ensure they stay focussed and motivated is apparent, but to be effective a more systematic understanding of the parameters of their work is required. This includes the tasks they fulfil, their relationship with colleagues and their organisation, and their attitudes and behaviour at work. This concept of understanding how the nature of work can reflect how well it is performed was first introduced by Herzberg [23] who described how jobs could be enriched and managed to foster responsibility and growth in competence. Building on this, the concept of job characteristics theory described how people would perform at their best when they were internally motivated to do so as opposed to the promise of some external reward or the threat of supervisory attention [24]. By its nature the design of an individual's work shapes the contribution made to the organisation and offers an understanding of the experiences and behaviours of employees [25]. This 'work design' is a critical component of human resource management that when understood and optimised improves job satisfaction, the quality, safety and efficiency of the work, $[26,27]$ and has positive impacts on performance, absenteeism and turnover $[28,29]$. In understanding work design and supporting its improvement the validated work design questionnaire (WDQ) [26], has proved a valuable tool producing benefits in a range of industries including information technology [30], nursing [31], and policing [32].

Whilst the most visible member of the practice team, the receptionist's role has largely been overlooked and to date there has been no detailed exploration of the 'work design' of GP receptionists; especially important in the context of the changing landscape of primary care. This study marks the first time that an England wide survey of GP receptionists aimed to understand the extent of their current role and importantly how we can help them remain motivated, productive and effective within a system of high demand and limited resource. Additionally, this study also marks the first use of the WDQ with this occupational group.

\section{Methods \\ Study design}

The study was designed as a large scale survey study of the job design of receptionists in England, utilising an existing validated questionnaire, the WDQ [26] (See supplementary material 1).

\section{Research instrument}

The WDQ [26] is a validated measure of work characteristics. It consists of a 21 point scale, divided into four groups each with sub-categories, responses to which are coded on a 5 point Likert Scale; from strongly disagree to strongly agree (Fig. 1). In addition, demographic details were collected for each participant including age, gender, disability, and ethnicity.

\section{Recruitment}

Receptionists are difficult to access as there is no overall list for practices in England; therefore, multiple recruitment methods were employed. These included disseminating the link to the online questionnaire via Clinical Commissioning Groups in England, Health Education England, Association of Medical Secretaries, Practice Managers, Administrators and Receptionists and GP surgeries working with the University of Birmingham. Bristol Online Survey hosted the survey and the link directed the respondent to an information page, consent was required. In addition, as most practices have more than one receptionist, 500 postal questionnaires were sent to 100 randomly selected GP practices across England between September 2016 and September 2017.

\section{Sampling}

All GP receptionists in England were eligible to participate. There were no exclusion criteria beyond job role. In 2014 (the most recent year for which there was data) there were 93,037 administrative and clerical staff in primary care, $67 \%$ of the primary care workforce [33]. Employing a 95\% confidence interval and a margin of error of .5 a sample of 384 was required.

\section{Analysis}

Following standard procedures for analysis of the WDQ [26], the respondent's scores were added together for each of the subscales, a mean was drawn, presented as a percentage of the total possible score. Responses were then categorised as low (score less than $50 \%$ of the total score), moderate (scores between 50 and $75 \%$ of the total 


\section{Work Design Questionnaire Categories}

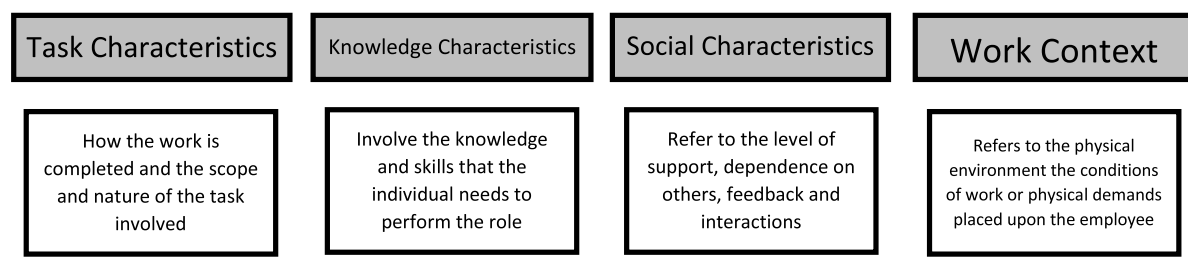

\section{Sub Categories}

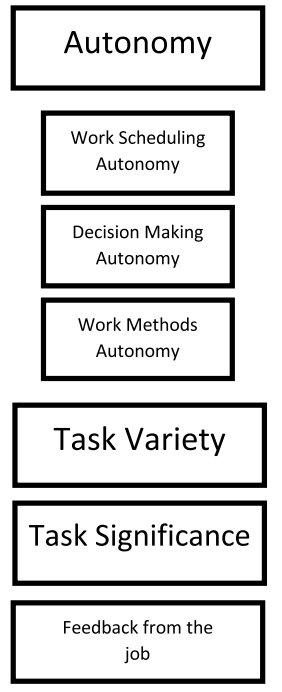

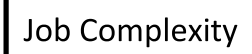

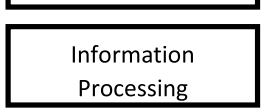

Problem Solving

Skills Variety

Specialization

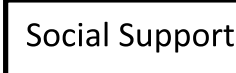

Interdependence

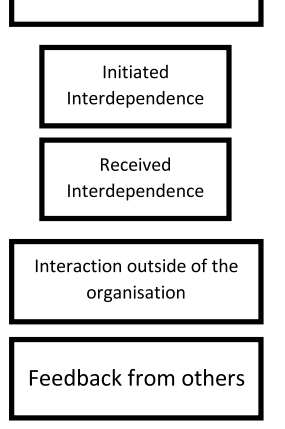

Ergonomics

Physical Demands

Work Conditions

Equipment Use

Fig. 1 Work Design Questionnaire, Categories and Sub Categories

score) and high (above $75 \%$ of the total score) for each subscale.

\section{Results}

Seventy receptionists completed the questionnaire, 16 postal questionnaires (3.1\% response rate) and 54 online questionnaires. Sixty-nine (99\%) were female, over half (56\%) were aged 40 and over, and nearly half $(49 \%)$ had been in post for longer than 5 years. These data are summarised in Table 1.

\section{Task characteristics}

Receptionists reported moderate levels of autonomy across the three subsets of work scheduling, decision making and work methods; decision making autonomy scored the highest (Mean score $[\mathrm{m}]=3.62,73 \%$ ). Both task variety $(M=4.25,85 \%)$ and significance $(M=4.03$, $85 \%)$ were high. Task identity relating to whether an individual undertakes a single overall task or contributes to a smaller aspect of a larger service was moderate $(\mathrm{M}=3.21,65 \%)$. Feedback from the job relates to the extent that the role itself provides 'direct and clear information' on the effectiveness of their performance [26] was scored as moderate by receptionists $(M=3.25,67 \%)$. These results are summarised in Fig. 2.

\section{Knowledge characteristics}

Knowledge characteristics include job complexity, the amount and type of information an individual must process to perform their role, the problem solving ability required, the variety of skills and the degree of specialisation required. Receptionists reported moderate complexity $(\mathrm{M}=3.81,75 \%)$ however informational processing demands were classified as high $(\mathrm{M}=3.81,75 \%)$. The need to develop original solutions and ideas was classed as moderate, bordering on high $(\mathrm{M}=3.74,75 \%)$. Skills variety was classed as high $(M=4.16,85 \%)$. Reflecting the degree to which the role requires a wide variety of skills the need for specialized or specific knowledge was scored as moderate by those we surveyed $(M=3.43,70 \%)$. These results are summarised in Fig. 3. 
Table 1 Participant characteristics

\begin{tabular}{|c|c|c|c|c|}
\hline Demographics & & & & \\
\hline \multicolumn{5}{|l|}{ Gender Identity (\%) } \\
\hline Female (\%) & Male (\%) & & & \\
\hline $69(99)$ & $1(1)$ & & & \\
\hline \multicolumn{5}{|l|}{ Age Range years (\%) } \\
\hline $18-28$ & $30-39$ & $40-49$ & $50-59$ & $60+$ \\
\hline $15(21)$ & $16(22)$ & $11(16)$ & $21(30)$ & $21(30)$ \\
\hline \multicolumn{5}{|l|}{ Level of Education (\%) } \\
\hline No Qualifications & GCSE/CSE & Further Education & A Levels & Bachelo \\
\hline $3(4)$ & $27(39)$ & $19(27)$ & $12(17)$ & $7(10)$ \\
\hline \multicolumn{5}{|l|}{ Marital Status (\%) } \\
\hline Single & Living with partner & Married/civil partnership & & \\
\hline $26(37.7)$ & $9(13)$ & $35(49.3)$ & & \\
\hline \multicolumn{5}{|l|}{ Disability (\%) } \\
\hline Yes & No & & & \\
\hline $2(2.9)$ & $68(97.1)$ & & & \\
\hline \multicolumn{5}{|c|}{ Sexual Orientation (\%) } \\
\hline Heterosexual & Gay woman/Lesbian & Gay Man & Bisexual & Other \\
\hline $65(96)$ & $1(1)$ & 0 & $2(3)$ & 0 \\
\hline \multicolumn{5}{|l|}{ Religious Belief (\%) } \\
\hline No Religion & Christian & Muslim & Other & \\
\hline $31(45.5)$ & $35(51.5)$ & $1(1.5)$ & $1(1.5)$ & \\
\hline \multicolumn{5}{|c|}{ Ethnic Background (\%) } \\
\hline White & Pakistani & Other & & \\
\hline $68(97)$ & $1(1.5)$ & $1(1.5)$ & & \\
\hline \multicolumn{5}{|c|}{ Occupational Characteristics } \\
\hline \multicolumn{5}{|l|}{ Time in post $(\%)^{b}$} \\
\hline $0-5$ Years & $6-10$ Years & $11-15$ Years & 16-20 Years & 21 Years \\
\hline $35(51)$ & $16(23)$ & $10(14)$ & $4(6)$ & $4(6)$ \\
\hline \multicolumn{5}{|c|}{ Respondents Practice Size $(\%)^{\mathrm{b}}$} \\
\hline Small & Medium & Large & & \\
\hline $4(6)$ & $38(55)$ & $27(39)$ & & \\
\hline \multicolumn{5}{|l|}{ Geographical range } \\
\hline Region $(\%)^{c}$ & & & & \\
\hline
\end{tabular}

\section{Occupational Characteristics}

Time in post $(\%)^{b}$

$\begin{array}{lllll}0-5 \text { Years } & 6-10 \text { Years } & 11-15 \text { Years } & 16-20 \text { Years } & 21 \text { Years + } \\ 35(51) & 16(23) & 10(14) & 4(6) & 4(6) \\ \text { Respondents } & \text { Practice } & \text { Size }(\%)^{\mathrm{b}} & & \\ \text { Small } & \text { Medium } & \text { Large } & \\ 4(6) & 38(55) & 27(39) & \end{array}$

\section{Geographical range}

Region (\%)$$
\text { E }
$$

30 (45) $\quad 9(14)$

South West

East Anglia North West

North East

East Midlands South East

${ }^{\mathrm{a}}$ completed by $68 / 70$ correspondents

b completed by $69 / 70$ correspondents

c completed by $66 / 70$ correspondents

The results from the WDQ are presented below where we describe the key findings in each of the four categories, with the means and percentages given for each sub-category. 


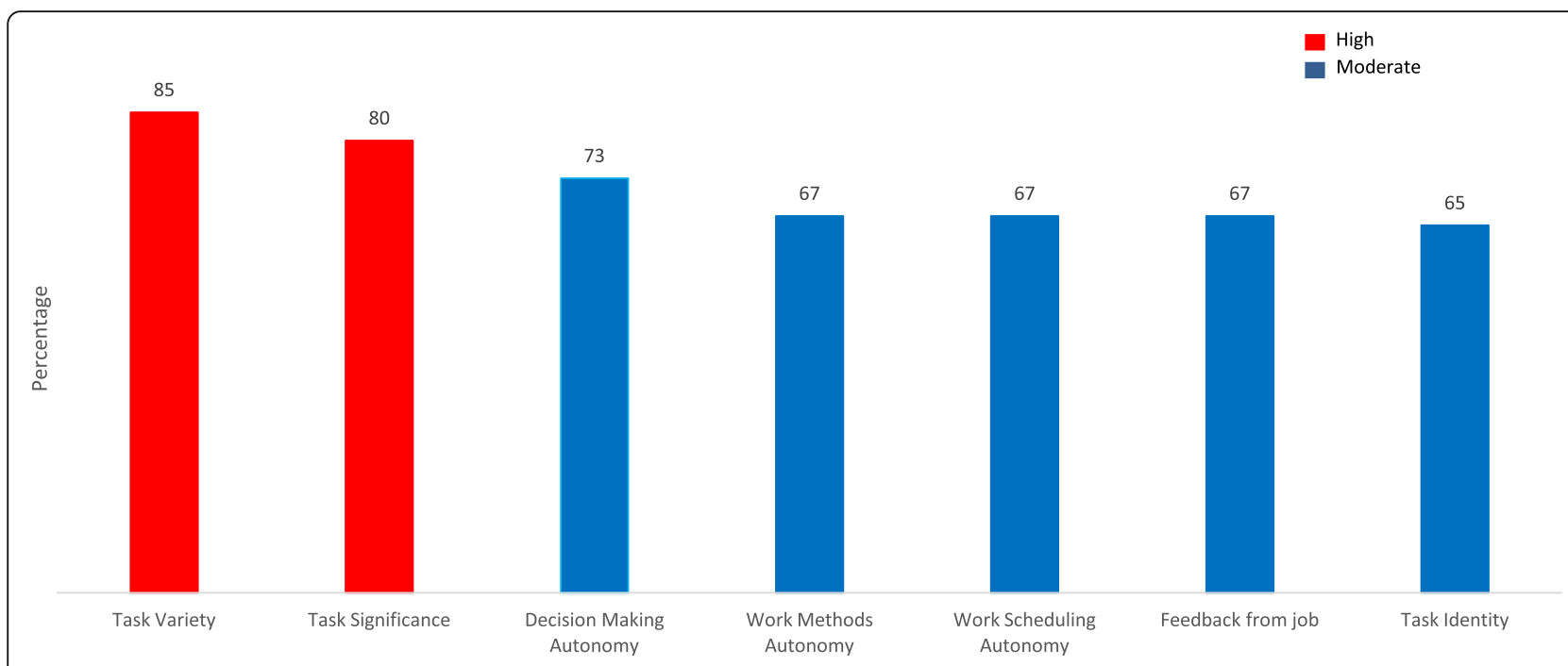

Fig. 2 Task Characteristics Subscales, percentage of total score

\section{Social characteristics}

The social characteristics of a role relate to various social or interpersonal aspects of the job and the degree of support, advice and assistance (needed and received) in the workplace and was classed as high $(\mathrm{M}=3.99,80 \%)$.

Interdependence was divided into either initiated independence, referring to the extent one job flows into others or received independence the extent that the one role is affected by work from other jobs and both were classed as moderate $(M=3.30,67 \%)$ and $(M=3.66$, $73 \%)$. Receptionists scored the level of interaction with external agencies as moderate $(M=3.41,73 \%)$ as they did feedback from their colleagues $(M=3.11,60 \%)$. These results are summarised in Fig. 4.

\section{Work context}

This covers the environment of the organisation in which the individual works and the physical demands placed on the employee in undertaking their roles. Receptionists scored the ergonomic value of their role as moderate $(M=3.51,73 \%)$, the physical activity and effort required as low $(M=1.96 .40 \%)$ and the variety and complexity of the equipment needed as moderate $(\mathrm{M}=$ $3.01,60 \%)$. Overall the working conditions which

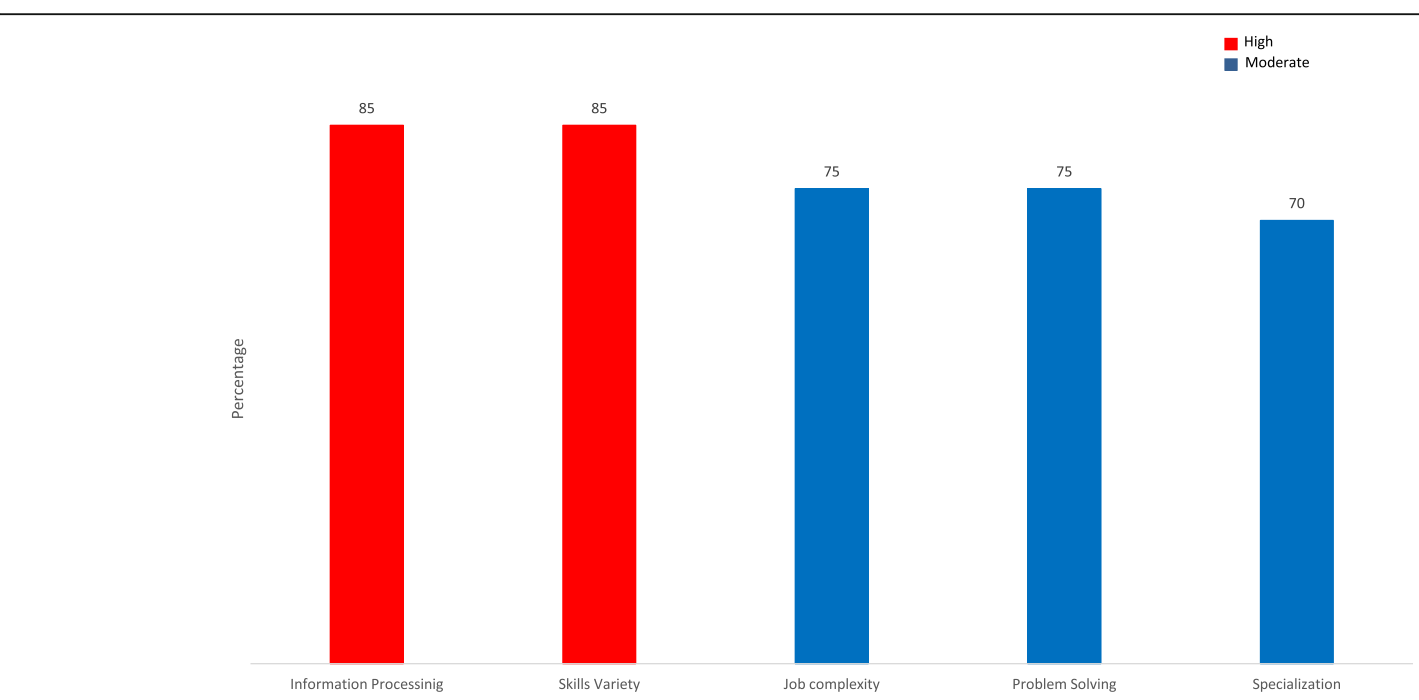

Fig. 3 Knowledge Characteristics Subscales, percentage of total score 


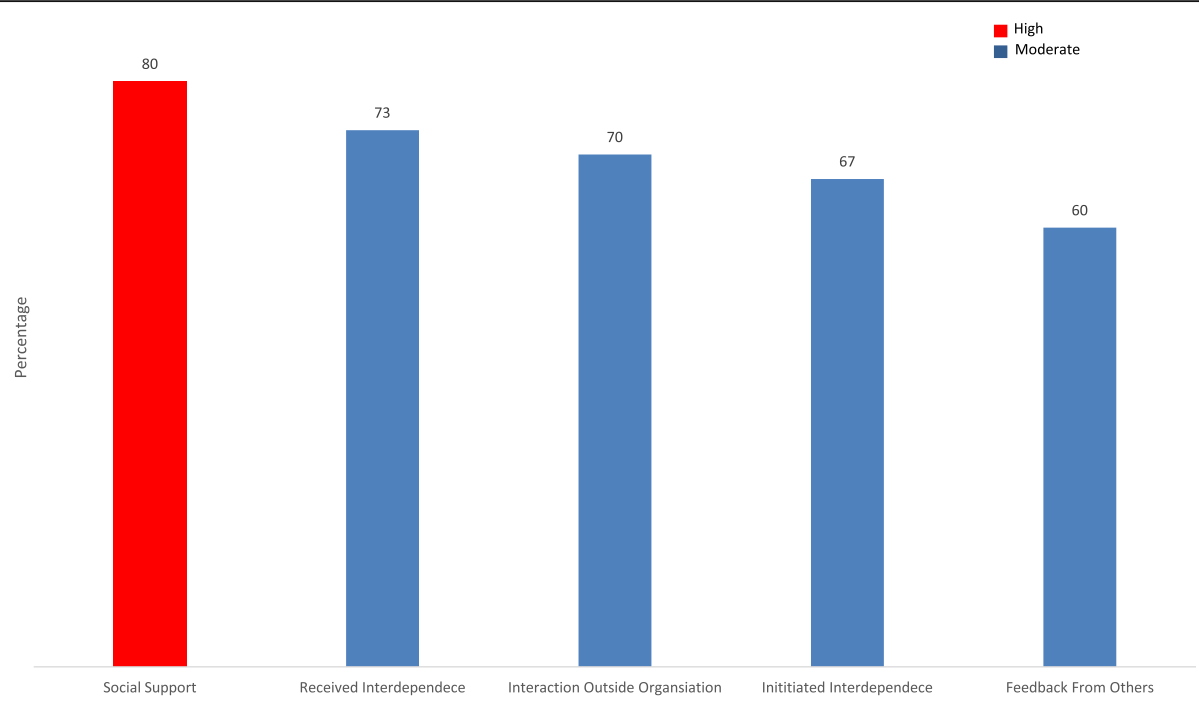

Fig. 4 Social Characteristics Subscales, percentage of total score

includes factors such as the existence of health hazards, cleanliness, noise were described as moderate $(M=3.43$, 68\%). These results are summarised in Fig. 5.

\section{Discussion}

\section{Summary}

We used Hackman and Oldham's theory of work design [28] to help us understand how the characteristics of a receptionist's roles can resonate psychologically in terms of the meaningfulness of work, the level of responsibility assumed and the outcomes of their work. These criteria are fundamental to intrinsic motivation, and how successful their work has been, enabling them to learn from mistakes and connect emotionally to the result of their actions.
Our participants reported a high level of autonomy and variety in the work they do though were relatively uncertain as to the success of their individual contribution. They were required to process a high level of information and employ a wide variety of skills yet did not regularly receive feedback from their colleagues. The ergonomic and physical impact of their work was low. Below we describe these findings in more detail within each of the four domains of the WDQ; Task characteristics, Knowledge characteristics, Social Characteristics, and Work Context.

\section{Strengths and limitations}

The survey was conducted amongst a number of GP practices and primary care environments across England

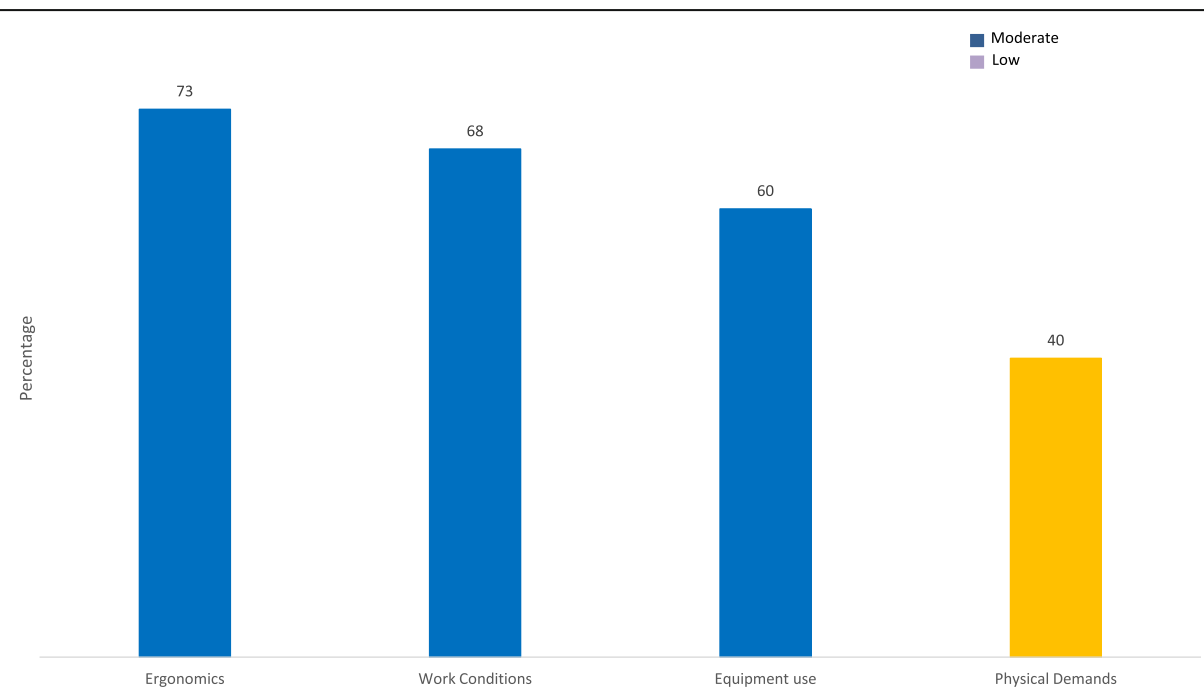

Fig. 5 Work Context Subscales, percentage of total score (moderate scores in blue, low in yellow) 
[34] and the WDQ provided the first quantitative insight into the parameters of the role of receptionists, highlighting key aspects of their work and suggesting areas where additional support may prove beneficial. However we do not claim our results are generalizable, as though the demographic characteristics of receptionists in our group reflect those of previous studies [10, $35,36]$; our sample size is smaller than preferred and so our findings do not necessarily reflect those of every receptionist and general practice. Unfortunately the recruitment of a broader sample of receptionists was hindered by the lack of a centralised list of reception staff in England, which is perhaps a contributory factor as to why they remain a seemingly hard to reach research population [37].

\section{Comparison with existing literature Task characteristics}

Increasingly, modern surgeries are multi-disciplinary teams consisting of clinical and non-clinical staff each undertaking a range of inter-related tasks to successfully deliver care [38-41]. As such the work the receptionist undertakes is varied [9-11, 42-45] and straddles both clinical and non-clinical responsibilities [9-11, 14, 16-19, $43,46-51]$. In doing so the receptionist juggles multiple sources of information from patients, colleagues, and external agencies often with competing demands on attention; for example booking patients into the practice while simultaneously taking phone calls $[17,52]$. High variety can be rewarding $[26,27]$ but can also lead to an overtaxed and underperforming workforce [26, 27].

In other environments such as aviation, issues of competing demands and multitasking have been tackled by introducing the idea of a 'sterile cockpit' which prohibits extraneous activities such as non-essential communication and reading non-essential materials during the critical phases of the flight [53]. Cognitive processing is undertaken serially and so multi-tasking is effectively "task-switching" between multiple tasks and so attention is shared sequentially [54]. This process slows down work and errors are more likely directly after the 'switch' has occurred $[54,55]$.

The implications of excessive cognitive load are especially important in healthcare where demand is high, information often incomplete and time constrained [5658]. Distractions, interruptions, and external extraneous stimuli disrupt attention and can lead to error $[56,57]$. Conversely, interruptions can be beneficial, offering information sharing needed for task completion [59], an alternate perspective, increasing positive affect [60] and when tasks are routine, distractions can speed information processing without concomitant negative effects on accuracy [59, 61]. For reception work, separating tasks may reduce the likelihood of error in complex tasks, for example separating greeting patients and answering the telephone into discrete roles may help to reduce error by minimising the interruptions encountered when undertaking these roles simultaneously. Similarly, complex work with potentially serious implications for patient safety such as repeat prescribing would benefit from being undertaken as a separate activity to reduce the cognitive load of multitasking [54, 55, 62].

\section{Knowledge characteristics}

The receptionist undertakes a number of roles that at times require specialised knowledge from triage $[15,20$, $21]$, to repeat prescribing $[21,22]$. However, no formal qualifications are required $[10,15]$ and much of the training that exists is provided in-house, from existing reception staff $[36,42,63,64]$ and viewed by receptionists as inadequate $[10,42,63,64]$. Barriers to improving this training including time constraints, and a lack of funding and relevant courses [65]. Recently this training shortfall has been acknowledged and in 2017 Health Education England, established a $£ 45$ million fund to support training in two discrete roles, managing medical correspondence and active care navigation [66] though its effect on quality, safety and staff is as yet unknown.

\section{Social characteristics}

Social support in the workplace helps underpin wellbeing $[67,68]$ and psychological and behavioural functioning [69] in a range of jobs and environments, including policing [70] hospitality [71] and healthcare [69, 72]. Our sample described the level of feedback as 'moderate' yet receptionists have previously described how important it is to their well-being and job satisfaction $[10,42]$. Though systematic mechanisms for providing feedback to receptionists exist, such as annual performance reviews and appraisals, [73] the time constrained and high pressured atmosphere of modern general practice precludes other avenues for providing the type of social support that might improve well-being [74]. This social connection also helps engender in reception staff a grasp of the outcomes of the work they complete. In other environments understanding the implications of their actions can help staff increase motivation and enable mistakes to be observed constructively [28] and could also be used to provide a framework for receptionists to monitor and improve performance.

\section{Work context}

Work environment directly affects an employee's ability to perform their role [25-29]. Receptionists are some of the most visible members of the practice team [16], their front of house position can bring them into contact with difficult or aggressive patients [75] or leave them feeling dissociated from the rest of the primary care team [42, 
43]. Although their location in the practice is unlikely to change, some of the negative effects might be mitigated by the opportunity for receptionists to share their experiences with supervisors and colleagues [76, 77].

The receptionist regularly uses information technology (IT) to manage patient data and service delivery. These clinical software systems are used to manage patient records, prescribing, test results and appointment bookings as well as facilitating communication from GPs to receptionists [78]. Despite their pivotal role a recent survey found that $12 \%$ of receptionists received no training in their use [65] despite evidence of errors linked to their misuse $[15,21]$. A sociotechnical perspective is one theory that has previously been adopted to improve the fit between individual and IT system and can be used to ensure the design of healthcare IT is informed by the context of the individual and their work environment [79].

\section{Conclusions}

Though receptionists continue to fulfil many of their traditional roles, the demands and complexity of modern primary care means they are being placed under increasing pressure to do so safely and effectively. Reducing cognitive load, improving training and feedback, and ensuring that IT systems harmonize with personnel and work practices can only help. Further research should aim to validate the findings from this study with a larger sufficiently powered sample. In addition, it would be helpful to design future studies in ways that are powered to detect differences between regions and types/size of practice. Meanwhile it is important that the issues identified by this study with respect to the receptionist's role within existing systems and processes are acknowledged and addressed as soon as possible.

\section{Supplementary information}

Supplementary information accompanies this paper at https://doi.org/10. 1186/s12875-020-01204-y.

\section{Additional file 1}

\section{Acknowledgements}

Not applicable.

Endnotes

Not applicable

\section{Authors' contributions}

IL, SG, NG and MB were responsible for the design of the study. MB collected and analysed the data in collaboration with IL and SG. MB produced the initial draft of the manuscript. This was then edited for content following the recommendations of IL, SG and NG. All authors read and approved the final manuscript.

\section{Funding}

This work was supported by The Health Foundation grant number 7452. They played no role in the design of the study, the collection, analysis or interpretation of the data, and the content or editing of this manuscript.

\section{Availability of data and materials}

All data generated or analysed during this study are included in this published article.

\section{Ethics approval and consent to participate}

Ethical approval was granted by the University of Birmingham's ethical board (ERN_15-1175). All participants provided written consent.

\section{Consent for publication}

Not applicable.

\section{Competing interests}

The authors declare that they have no competing interests.

\section{Author details}

${ }^{1}$ Institute of Applied Health Research, College of Medical and Dental Sciences, University of Birmingham, Edgbaston, Birmingham B15 2TT, UK. ${ }^{2}$ Present Address: School of Psychological, Social and Behavioural Sciences, Faculty of Health \& Life Sciences, Coventry University, Priory St., Coventry, CV1 5FB Birmingham, UK. ${ }^{3}$ School of Social Policy, HSMC Park House, University of Birmingham, Birmingham, UK.

Received: 26 June 2019 Accepted: 22 June 2020

Published online: 10 July 2020

\section{References}

1. RCGP. GP receptionists integral to patient care, says RCGP 2016 [Available from: http://www.rcgp.org.uk/about-us/news/2016/august/gp-receptionistsintegral-to-patient-care-says-rcgp.aspx.

2. British Medical Association. General practice in the UK - background briefing. 2017

3. Jones $R$, Newbold M, Reilly J, Drinkwater $R$, Stoate $H$. The future of primary and secondary care. Br J Gen Pract. 2013;63(612):379-82.

4. Stokes-Lampard H. Time to tackle GP workforce pressures, says RCGP in response to GMC report 2017 [Available from: http://www.rcgp.org.uk/ about-us/news/2017/december/time-to-tackle-gp-workforce-pressures-saysrcgp-in-response-to-gmc-report.aspx.

5. Cassell A, Edwards D, Harshfield A, Rhodes K, Brimicombe J, Payne R, et al. The epidemiology of multimorbidity in primary care: a retrospective cohort study. Br J Gen Pract. 2018;68(669):e245-e51.

6. Jaques $\mathrm{H}$. Number of singlehanded GPs in England has nearly halved since 2002. BMJ. 2013;346:f2473.

7. van den Hombergh P, Engels $Y$, van den Hoogen $H$, van Doremalen J, van den Bosch W, Grol R. Saying 'goodbye' to single-handed practices; what do patients and staff lose or gain? Fam Pract. 2005;22(1):20-7.

8. Baird B, Charles A, Honeyman M, Magurie D, Das P. Understanding pressures in general practice. London: The King's Fund; 2016.

9. Buchan IC, Richardson IM. Receptionists at work. A time study in general practice. J Royal Coll Gen Pract. 1972;22(118):331-4.

10. Copeman JP, Zwanenberg TDV. Practice receptionists: poorly trained and taken for granted? J Royal Coll Gen Pract. 1988;38(306):14-6.

11. Hammond J, Gravenhorst K, Funnell E, Beatty S, Hibbert D, Lamb J, et al. Slaying the dragon myth: an ethnographic study of receptionists in UK general practice. Br J Gen Pract. 2013;63(608):e177-84.

12. Litchfield I, Bentham L, Hill A, McManus RJ, Lilford R, Greenfield S. Routine failures in the process for blood testing and the communication of results to patients in primary care in the UK: a qualitative exploration of patient and provider perspectives. BMJ Qual Saf. 2015;24(11):681-90.

13. Litchfield IJ, Bentham LM, Lilford RJ, McManus RJ, Greenfield SM. Patient perspectives on test result communication in primary care: a qualitative study. Br J Gen Pract. 2015;65(632):e133-40.

14. Hesselgreaves $H$, Lough $M$, Power $A$. The perceptions of reception staff in general practice about the factors influencing specific medication errors. Educ Prim. Care. 2009;20(1):21-7. 
15. Swinglehurst D, Greenhalgh T, Russell J, Myall M. Receptionist input to quality and safety in repeat prescribing in UK general practice: ethnographic case study. BMJ. 2011;343.

16. Arber $S$, Sawyer $L$. The role of the receptionist in general practice: a 'dragon behind the desk'? Soc Sci Med. 1985;20(9):911-21.

17. Gallagher M, Pearson P, Drinkwater C, Guy J. Managing patient demand: a qualitative study of appointment making in general practice. $\mathrm{Br} J$ Gen Pract. 2001;51(465):280-5.

18. Mellor RM, Sheppard JP, Bates E, Bouliotis G, Jones J, Singh S, et al. Receptionist rECognition and rEferral of patients with stroke (RECEPTS): unannounced simulated patient telephone call study in primary care. Br J Gen Pract. 2015;65(636):e421-e7.

19. Sheppard JP, Singh S, Jones J, Bates E, Skelton J, Wiskin C, et al. Receptionist rECognition and rEferral of PaTients with stroke (RECEPTS) study - protocol of a mixed methods study. BMC Fam Pract. 2014;15:91.

20. Grant S, Checkland K, Bowie P, Guthrie B. The role of informal dimensions of safety in high-volume organisational routines: an ethnographic study of test results handling in UK general practice. Implement Sci. 2017;12(1):56.

21. Zermansky AG. Who controls repeats? Br J Gen Pract. 1996;46(412):643-7.

22. Grant S, Mesman J, Guthrie B. Spatio-temporal elements of articulation work in the achievement of repeat prescribing safety in UK general practice. Sociol Health IIIn. 2016;38(2):306-24.

23. Herzberg F, Mausner B, Snyderman B. The motivation to work, 2nd ed. Oxford, England: John Wiley; 1959. xv, 157-xv, p.

24. Sashkin M. WORK REDESIGN J. R. Hackman and G. R. Oldham Reading, MA: Addison-Wesley, 1980, xxvii + 330 pp. 1982;7(1):121-4.

25. Grant AM, Parker SK. Redesigning work design theories: the rise of relational and proactive perspectives. Acad Manag Ann. 2009;3(1):317-75.

26. Morgeson FP, Humphrey SE. The work design questionnaire (WDQ): developing and validating a comprehensive measure for assessing job design and the nature of work. J Appl Psychol. 2006:91(6):1321-39.

27. Torraco RJ. Work design theory: a review and critique with implications fo human resource development. Hum Resour Dev Q. 2005;16(1):85-109.

28. Hackman JR, Oldham GR. Motivation through the design of work: test of a theory. Organ Behav Hum Perform. 1976;16(2):250-79.

29. Yitzak F, Ferris GR. The validity of the job characteristics model: a review and meta-analysis. Pers Psychol. 1987:40(2):287-322.

30. Uruthirapathy AA, Grant GG. The influence of job characteristics on IT and nonIT job professional's turnover intentions. J Manage Dev. 2015;34(6):715-28.

31. Portoghese I, Galletta M, Battistelli A, Leiter MP. A multilevel investigation on nursing turnover intention: the cross-level role of leader-member exchange. J Nurs Manag. 2015;23(6):754-64.

32. Hsieh WC, Vivian Chen $\mathrm{CH}$, Lee CC, Kao RH. Work characteristics and police officers' performance: exploring the moderating effect of social work characteristics and collective efficacy in multilevel analysis. Policing: Int J. 2012:35(3):615-41.

33. HSCIC. General and Personal Medical Services in England 2004-2014 London: Health and Social Care Information Centre; 2014 [43]. Available from: https://digital.nhs.uk/data-and-information/publications/statistical/ general-and-personal-medical-services/2004-2014-as-at-30-september.

34. Kelly E, Stoye G. Does GP practice size matter? GP practice size and the quality of primary care. London: The Institute for Fiscal Studies; 2014.

35. Heuston J, Groves P, Nawad JA, Albery I, Gossop M, Strang J. Caught in the middle: receptionists and their dealings with substance misusing patients. J Subst Abus. 2001;6(3):151-7.

36. Mulroy R. Ancillary staff in general practice. J Royal Coll Gen Pract. 1974; 24(142):358-61.

37. Shaghaghi A, Bhopal RS, Sheikh A. Approaches to recruiting 'hard-to-reach' populations into re-search: a review of the literature. Health Promot Perspect. 2011;1(2):86-94.

38. Jaruseviciene L, Liseckiene I, Valius L, Kontrimiene A, Jarusevicius G, Lapão LV. Teamwork in primary care: perspectives of general practitioners and community nurses in Lithuania. BMC Fam Pract. 2013;14(1):118

39. Saba GW, Villela TJ, Chen E, Hammer H, Bodenheimer T. The myth of the lone physician: toward a collaborative alternative. Ann Fam Med. 2012;10.

40. Babiker A, El Husseini M, Al Nemri A, Al Frayh A, Al Juryyan N, Faki MO, et al. Health care professional development: working as a team to improve patient care. Sudanese J Paediatr. 2014;14(2):9-16.

41. O'Reilly P, Lee SH, O'Sullivan M, Cullen W, Kennedy C, MacFarlane A. Assessing the facilitators and barriers of interdisciplinary team working in primary care using normalisation process theory: an integrative review. PLoS One. 2017:12(5):e0177026.

42. Eisner M, Britten N. What do general practice receptionists think and feel about their work? Br J Gen Pract. 1999:49(439):103-6.

43. Hewitt H, McCloughan L, McKinstry B. Front desk talk: discourse analysis of receptionist-patient interaction. Br J Gen Pract. 2009;59(565):e260-6.

44. Neuwelt PM, Kearns RA, Browne AJ. The place of receptionists in access to primary care: challenges in the space between community and consultation. Soc Sci Med. 2015;133:287-95

45. Ward J, McMurray R. The unspoken work of general practitioner receptionists: a re-examination of emotion management in primary care. Soc Sci Med. 2011;72(10):1583-7.

46. McNulty CA, Freeman E, Oliver I, Ford-Young W, Randall S. Strategies used to increase chlamydia screening in general practice: a qualitative study. Public Health 2008:122(9):845-56.

47. Eskerud JR, Laerum E, Fagerthun H, Lunde PK, Naess A. Fever in general practice. i frequency and diagnoses. Fam Pract. 1992;9(3):263-9.

48. Patterson E, Forrester K, Price K, Hegney D. Risk reduction in general practice and the role of the receptionist. J Law Med. 2005;12(3):340-7.

49. Patterson EA, Del Mar C, Najman JM. Medical receptionists in general practice: who needs a nurse? Int J Nurs Pract. 2000;6(5):229-36.

50. Orchard J, Freedman SB, Lowres N, Neubeck L. Screening education and recognition by primary care physician of atrial fibrillation to prevent stroke (search-AF II stroke prevention study) and the role of general practice receptionists. Global Heart. 2014;(1):e165.

51. Orchard J, Freedman SB, Lowres N, Peiris D, Neubeck L. iPhone ECG screening by practice nurses and receptionists for atrial fibrillation in general practice: the GP-SEARCH qualitative pilot study. Aust Fam Physician. 2014;43(5):315-9.

52. McKinstry B, Watson P, Pinnock H, Heaney D, Sheikh A. Confidentiality and the telephone in family practice: a qualitative study of the views of patients, clinicians and administrative staff. Fam Pract. 2009;26(5):344-50.

53. Young MS. The multitasking myth: handling complexity in real-world operations. L. D. Loukopoulos, R. K. Dismukes, \& I. Barshi. Ashgate, Farnham, Surrey: England. 2009. No. of pages: 188+xiv. ISBN 978-0-7546-7382-8, (hardback). ISBN 978-0-7546-7997-4 (paperback). Appl Cogn Psychol. 2010; 24(7):1046-7.

54. Kiesel A, Steinhauser M, Wendt M, Falkenstein M, Jost K, Philipp AM, et al. Control and interference in task switching--a review. Psychol Bull. 2010; 136(5):849-74.

55. Monsell S. Task switching. Trends Cogn Sci. 2003;7(3):134-40.

56. Laxmisan A, Hakimzada F, Sayan OR, Green RA, Zhang J, Patel VL. The multitasking clinician: decision-making and cognitive demand during and after team handoffs in emergency care. Int J Med Inform. 2007;76(11-12): 801-11.

57. Forsberg HH, Muntlin Athlin A, von Thiele Schwarz U. Nurses' perceptions of multitasking in the emergency department: effective, fun and unproblematic (at least for me) - a qualitative study. Int Emerg Nurs. 2015 23(2):59-64.

58. Reason JT. Human Error. Cambridge, England: Cambridge University Press; 1990.

59. Jett QR, George JM. Work interrupted: a closer look at the role of interruptions in organizational life. Acad Manag Rev. 2003;28(3):494-507.

60. Mochi F, Madjar N. Chapter 5 - Interruptions and Multitasking: Advantages and Disadvantages for Creativity at Work. In: Reiter-Palmon R, Kennel VL, Kaufman JC, editors. Individual Creativity in the Workplace: Academic Press; 2018. p. 103-27.

61. Zijlstra FRH, Roe RA, Leonora AB, Krediet I. Temporal factors in mental work: Effects of interrupted activities. 1999;72(2):163-85.

62. Appelbaum SH, Marchionni A, Fernandez A. The multi-tasking paradox: perceptions, problems and strategies. Manag Decis. 2008;46(9):1313-25.

63. Hayes $\mathrm{E}$. The role of the receptionist in general practice: a survey of receptionists in general practice to evaluate their attitudes to their jobs, and their training. Cardiff?: department of Sociology; 1987.

64. Hayes E. GP receptionists: their work and training. Health Visit. 1989;62(4): $117-8$.

65. Burrows M, Greenfield S, Gale N, Walsh F, Litchfield I. General Practice Receptionists, Visible but Invisible: The Forgotten Workforce. [Research Report]. In press 2020

66. NHS England. General Practice Forward View 2016 [Available from: https://www.england.nhs.uk/wp-content/uploads/2016/04/gpfv.pdf. 
67. Wrzesniewski A, Dutton JE, Debebe G. Interpersonal sensemaking and the meaning of work. In: Kramer RM, Staw BM, editors. Research in organizational behavior. Amsterdam: Elsevier; 2003.

68. Ryan RM, Deci EL. On happiness and human potentials: a review of research on hedonic and eudaimonic well-being. Annu Rev Psychol. 2001;52(1):141-66.

69. Harris II, Winskowski AM, Engdahl BE. Types of workplace social support in the prediction of job satisfaction. Career Dev Q. 2007;56(2):150-6.

70. Brown JM, Campbell EA. Sources of occupational stress in the police. Work \& Stress. 1990;4(4):305-18.

71. Tews MJ, Michel JW, Ellingson JE. The impact of coworker support on employee turnover in the hospitality industry. Group Organ Manage. 2013; 38(5):630-53.

72. Park KO, Wilson MG, Lee MS. Effects of social support at work on depression and organizational productivity. Am J Health Behav. 2004;28(5):444-55.

73. Practice Index. How to Give a Good Appraisal For Your GP Practice Staff 2014 [Available from: https://practiceindex.co.uk/gp/blog/gp-practice-staffappraisals/.

74. Hardavella G, Aamli-Gaagnat A, Saad N, Rousalova I, Sreter KB. How to give and receive feedback effectively. Breathe (Sheff). 2017;13(4):327-33.

75. Bayman PA, Hussain T. Receptionists' perceptions of violence in general practice. Occup Med (Lond). 2007;57(7):492-8.

76. Greenglass ER, Burke RJ, Konarski R. The impact of social support on the development of burnout in teachers: examination of a model. Work Stress. 2007;11(3):267-78.

77. Hogan R, Curphy GJ, Hogan J. What we know about leadership: effectiveness and personality. Am Psychol. 1994:49(6):493-504.

78. Castle-Clarke S, Imison C. The digital patient: transforming primary care? ; 2016

79. Carayon P. Sociotechnical systems approach to healthcare quality and patient safety. Work (Reading, Mass). 2012;41(Suppl 1(0 1)):3850-4.

\section{Publisher's Note}

Springer Nature remains neutral with regard to jurisdictional claims in published maps and institutional affiliations.

Ready to submit your research? Choose BMC and benefit from:

- fast, convenient online submission

- thorough peer review by experienced researchers in your field

- rapid publication on acceptance

- support for research data, including large and complex data types

- gold Open Access which fosters wider collaboration and increased citations

- maximum visibility for your research: over $100 \mathrm{M}$ website views per year

At $\mathrm{BMC}$, research is always in progress.

Learn more biomedcentral.com/submissions 